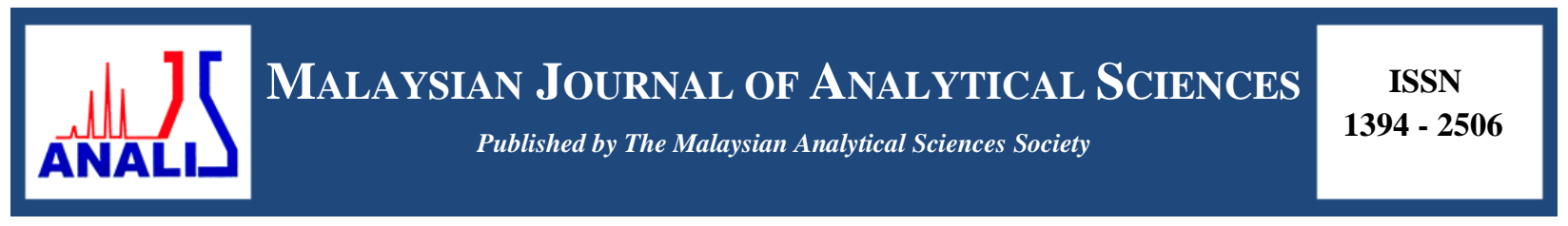

\title{
PdAu BIMETALLIC CATALYST FOR ELECTROOXIDATION OF GLYCEROL USING CYCLIC VOLTAMMETRY ANALYSIS
}

\section{(PdAu Dwilogam Mangkin untuk Elektropengoksidaan Gliserol dengan Menggunakan Analisis Kitaran Voltametri)}

\author{
Norilhamiah Yahya ${ }^{1}$ and Siti Kartom Kamaruddin ${ }^{2,3} *$ \\ ${ }^{I}$ Malaysian Institute of Chemical and Bioengineering Technology, \\ Universiti Kuala Lumpur, 78000 Alor Gajah, Melaka, Malaysia. \\ ${ }^{2}$ Fuel Cell Institute \\ ${ }^{3}$ Department of Chemical and Process Engineering
}

Universiti Kebangsaan Malaysia, 43600 UKM Bangi, Selangor, Malaysia.

*Corresponding author: ctie@ukm.edu.my

Received: 13 April 2017; Accepted: 17 April 2018

\begin{abstract}
This study was conducted to examine the performance of Palladium (Pd) based catalyst for glycerol oxidation in alkaline media by using half-cell in a cyclic voltammetry study. The sonication assisted reduction method by sodium citrate and sodium borohydride was employed to prepare a bimetallic $\mathrm{PdAu}$ catalyst. The crystallinity data of bimetallic $\mathrm{Pd}_{2} \mathrm{Au}_{1}$ and $\mathrm{Pd}_{4} \mathrm{Au}_{1}$ catalysts were characterised by powder X-ray powder diffraction (XRD). Meanwhile, morphology, rough composition and distribution of metallic elements from both catalysts were investigated by Field Emission Scanning Electron Microscope (FESEM) and Energy Dispersive X-ray (EDX), respectively. The performances of the synthesised catalysts were analysed for the electrooxidation of glycerol in alkaline media by cyclic voltammetry analysis and chronoamperometry analysis. It was found that $\mathrm{Pd}_{2} \mathrm{Au}_{1}$ showed higher performance in terms of peak current density $\left(55.28 \mathrm{~mA} \mathrm{~cm}{ }^{-2}\right)$, onset potential $(-0.4152 \mathrm{~V})$ and more stability towards glycerol oxidation compared to $\mathrm{Pd}_{4} \mathrm{Au}_{1}$. The cyclic voltammetry study yielded an electrochemically active surface area for $\mathrm{Pd}_{2} \mathrm{Au}_{1}$ catalyst at $14.12 \mathrm{~m}^{2} \mathrm{~g}^{-1}$, compared to $\mathrm{Pd}_{4} \mathrm{Au}_{1}$ catalyst at only $12.7 \mathrm{~m}^{2} \mathrm{~g}^{-1}$.
\end{abstract}

Keywords: PdAu, nanocatalyst, alkaline medium, glycerol oxidation, cyclic voltammetry

\begin{abstract}
Abstrak
Kajian ini adalah untuk mengkaji prestasi mangkin berasaskan Palladium (Pd) untuk pengoksidaan gliserol dalam media alkali dengan menggunakan sel separuh dalam kajian voltammetri berkitar. Kaedah sonikasi dibantu kaedah penurunan oleh natrium sitrat dan natrium borohidrat telah digunakan untuk menyediakan mangkin dwilogam PdAu. Data penghabluran mangkin dwilogam $\mathrm{Pd}_{2} \mathrm{Au}_{1}$ dan $\mathrm{Pd}_{4} \mathrm{Au}_{1}$ telah dicirikan oleh pembelauan sinar-X (XRD). Sementara itu, morfologi, komposisi kasar dan taburan unsur logam daripada mangkin telah disiasat menggunakan mikroskopi elektron imbasan (FESEM) dan spektrometer serakan tenaga sinar-X (EDX). Prestasi mangkin yang disintesis dianalisa untuk melihat tindakbalas elektropengoksidaan gliserol

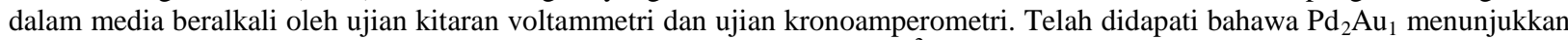
prestasi yang lebih tinggi dari segi ketumpatan arus puncak $\left(55.28 \mathrm{~mA} \mathrm{~cm}^{-2}\right)$, permulaan keupayaan potensi (-0.4152V) dan lebih kestabilan terhadap pengoksidaan gliserol dibandingkan dengan $\mathrm{Pd}_{4} \mathrm{Au}_{1}$. Kajian kitaran voltammetri menghasilkan kawasan permukaan elektrokimia aktif untuk mangkin $\mathrm{Pd}_{2} \mathrm{Au}_{1}$ sebanyak $14.12 \mathrm{~m}^{2} \mathrm{~g}^{-1}$, di bandingkan dengan mangkin $\mathrm{Pd}_{4} \mathrm{Au}_{1}$ hanya sebanyak $12.7 \mathrm{~m}^{2} \mathrm{~g}^{-1}$.
\end{abstract}

Kata kunci: $\mathrm{PdAu}$, nanomangkin, media alkali, pengoksidaan gliserol, kitaran voltammetri 


\section{Introduction}

Direct alcohol fuel cell has emerged as one of the alternative energies used to generate electricity without any combustion [1-3]. There are many types of fuel candidates used to replace fuel, one of which is methanol due to its high toxicity, high methanol crossover and slow electro-kinetic properties $[4,5]$. This makes methanol unsuitable as a fuel for the commercialisation of fuel cell. One alternative being currently proposed is glycerol to replace methanol in fuel cell application. Glycerol can be obtained from various sources and one of them is from biodiesel production [6, 7]. Lately, research effort has been done to use glycerol as fuel in fuel cell application to convert glycerol as a value-added product [8]. Glycerol as fuel in fuel cell application has gained attention because of its attractive fuel components which are renewable from biomass production, less harmful, have high energy density, low vapour pressure, low cost, easy to store and low transportation needs [8]. On the other hand, theoretically, when glycerol is oxidised by inorganic catalysts, it is possible to obtain 10 electrons (when the reaction is not complete) against 14 electrons for a complete oxidation [9].

However, oxidation of glycerol is quite difficult and complicated due to the complex molecular structure in which partial oxidation will produce unwanted products such as glyceraldehyde, 1,3-dihydroxyacetone, glyceric acid, hydroxypyruvic acid, tartronic acid, mesoxalic acid, formic acid, ocilic acid and glycolic acid [10, 11]. All these partial oxidation products are not desirable as they will decrease the overall system efficiency. This becomes the primary challenge of glycerol oxidation. Due to this, selection of catalyst is the critical issue to increase the activity of glycerol oxidation in the anode side and at the same time minimise the cost of the fuel cell itself. Up until now, there are several catalysts used to study the oxidation of glycerol such as platinum and palladium (Pd). However, the use of platinum has brought another issue such as higher price and limited source [12]. In addition, platinum creates stability issues with another intermediate product of carbon monoxide poisoning of the platinum surface by adsorbing too strong on the platinum surface [13].

To overcome the problem, Palladium-Aurum $(\mathrm{PdAu})$ bimetallic catalyst has been used in this study. Pd (111) and $\mathrm{Au}$ (111) planes are only 4\% mismatched, making the combination Pd and Au perfect to be a miscible solution. Several previous studies showed that due to ensemble and ligand effect, this combination will enhance the electrocatalytic activity in terms of current density and tolerance to the carbon monoxide poisoning effect [14, 15]. To synthesise heterogeneous catalysts with small nanoparticles (less than $20 \mathrm{~nm}$ ), highly dispersed and less agglomeration with high surface area are among the challenges. The physical-chemical concepts needed to understand the preparation of colloidal inorganic nanoparticles and the remarkable degree of control that has been achieved over their composition, size, shape and surface [16]. In this study, chemical reduction modified the classical "Turkevich" preparation method which has been used to synthesise PdAu nanoparticles in control temperature [17] as the catalyst in glycerol oxidation.

\section{Materials}

\section{Materials and Methods}

All precursor metal salts and chemical reagents such as Gold(III) chloride trihydrate $\left(\mathrm{HAuCl}_{4} \cdot 3 \mathrm{H}_{2} \mathrm{O}\right), \mathrm{Palladium}$ chloride $\left(\mathrm{PdCl}_{2}\right)$, Trisodium citrate $\left(\mathrm{Na}_{3} \mathrm{Ct}\right)$, Sodium borohydride $\left(\mathrm{NaBH}_{4}\right)$, vapour grown carbon nanofiber (VGCNF), Sodium hydroxide, glycerin, 2-propanol and 5 wt.\% nafion solution were purchased from SigmaAldrich/USA.

\section{Synthesis of PdAu catalysts via chemical reduction method}

$0.05 \mathrm{M} \mathrm{PdCl}_{2}$ (Sigma-Aldrich/USA) and $0.01 \mathrm{M}$ of $\mathrm{AuCl}_{3} \cdot \mathrm{HCl} \cdot 4 \mathrm{H}_{2} \mathrm{O}($ Sigma-Aldrich/USA) were mixed (in $2: 1$ and 4:1 molar ratio) in a volumetric flask and sonicated for 2 hours to form a homogenous solution. A certain amount of trisodium citrate was added into the solution in a drop wise manner with constant stirring for another 2 hours [18]. The presence of a capping agent in this study is to inhibit the nanoparticles' over-growth and aggregation during the reduction process. Next, reduction of the metal precursors is carried out using an excess amount of freshly prepared ice-cold $(0.3 \mathrm{M})$ sodium borohydride $\left(\mathrm{NaBH}_{4}\right)$ and the reduction was assisted by sonication for 3 hours. Since the stabilising and reducing agents are water soluble, the solvent can be removed by filtration and washing with DI water and dried at $80^{\circ} \mathrm{C}$ overnight. 


\section{Physical and electrochemical characterization of nanoparticles}

XRD is a powerful method used for characterising crystalline materials of the metal synthesis. The samples of X-ray data were collected in the $2 \theta$ range of $20^{\circ}$ to $90^{\circ}$. The FESEM analyses were performed using FESEM model Zeiss/SUPRA 55VP. FESEM analyses provide information about the morphology and topography of the catalyst samples. Meanwhile, EDX analysis normally determines the average surface elemental composition as well as elemental distribution mapping of the catalyst samples

The cyclic voltammetry and chronoamperometry analyses measurements were performed by using Autolab (PGSTAT101) electrochemical workstation under room temperature. The catalysts' ink solution was carefully transferred onto the glassy carbon electrode by using a micropipette and then left to dry in room temperature. The electrochemical characterisation of two types of catalysts was studied by a cyclic voltammetry (CV) test in the potential range of -0.7 to $0.4 \mathrm{~V}$ at a scan rate of $50 \mathrm{mV} \mathrm{s}^{-1}$ in $0.5 \mathrm{M}$ glycerol/ $/ 0.5 \mathrm{M} \mathrm{NaOH}$ solution. The electrolyte solution was de-oxygenated by bubbling it with $\mathrm{N}_{2}$ at $200 \mathrm{~mL} \mathrm{~min}^{-1}$ for 30 minutes before taking any measurement of glycerol oxidation reaction.

\section{Results and Discussion}

XRD is a primary tool used to identify crystalline material structures. Figure 1 shows the XRD patterns which confirmed the presence of target metal in the catalyst samples of $\mathrm{Pd}_{2} \mathrm{Au}_{1}$ and $\mathrm{Pd}_{4} \mathrm{Au}_{1}$ that fit well with their characteristic of face-centred cubic (fcc) patterns. Table 1 shows the lattice parameter, crystallite size and atomic composition for each catalyst. The diffraction peaks in the catalyst sample $\mathrm{Pd}_{2} \mathrm{Au}_{1}$ exhibited the characteristic of face-centred cubic crystalline structure at $2 \theta$ values of $38.28^{\circ}, 44.19^{\circ}, 64.92^{\circ}$, and $77.40^{\circ}$ which corresponded to the (111), (200), (220) and (311) planes. The diffraction peaks of $\mathrm{Pd}_{4} \mathrm{Au}_{1}$ are $39.15^{\circ}, 44.64^{\circ}, 65.12^{\circ}$, and $78.02^{\circ}$ which corresponded to the (111), (200), (220) and (311) planes. The differences of diffraction peak positions for $\mathrm{Pd}_{2} \mathrm{Au}_{1}$ and $\mathrm{Pd}_{4} \mathrm{Au}_{1}$ indicate that $\mathrm{Au}$ has entered the $\mathrm{Pd}$ lattice and formed a homogeneous substitution of bimetallic nanoparticles [19]. The lattice parameter for $\mathrm{Pd}_{2} \mathrm{Au}_{1}$ and $\mathrm{Pd}_{4} \mathrm{Au}_{1}$ is exposed alloy with the dissolution of $\mathrm{Au}$ to $\mathrm{Pd}$ which made the lattice parameter increased from pure, which was $P d(0.3857 \mathrm{~nm})$ [20] to $0.3991 \mathrm{~nm}$ and $0.3892 \mathrm{~nm}$ for $\mathrm{Pd}_{2} \mathrm{Au}_{1}$ and $\mathrm{Pd}_{4} \mathrm{Au}_{1}$, respectively. The average crystallite size for the synthesised catalysts was calculated based on the plane (111) diffraction peak using Scherrer's equation 1:

$$
\mathrm{d}_{\mathrm{XRD}}=0: 9 \lambda_{\mathrm{CuKa}} / \beta 2 \theta \cdot \cos \theta \max
$$

where $\mathrm{d}$ is the average particle size $(\mathrm{nm}), \lambda$ is the wavelength of the $\mathrm{X}$-ray used (1.54056 $\AA$ ), $\theta$ is the angle at the maximum of the peak (rad), and $\beta_{2 \mathrm{~A}}$ is the width of the peak at half height in radians. The calculated average crystallite sizes obtained for both catalysts $\mathrm{Pd}_{2} \mathrm{Au}_{1}$ and $\mathrm{Pd}_{4} \mathrm{Au}_{1}$ are given in Table 1 .

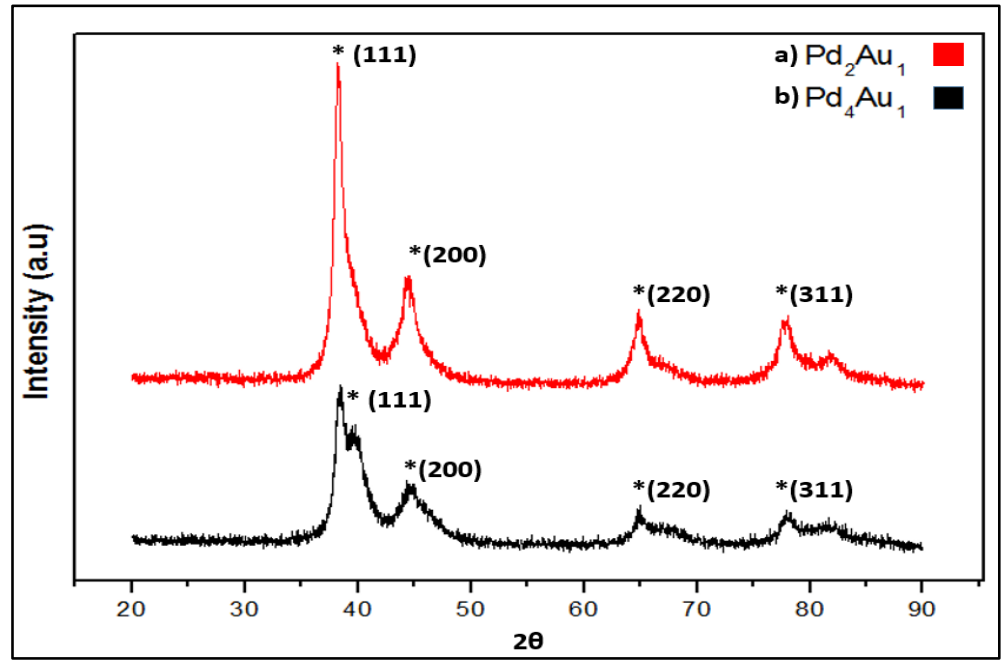

Figure 1. XRD patterns for a) $\mathrm{Pd}_{2} \mathrm{Au}_{1}$ and b) $\mathrm{Pd}_{4} \mathrm{Au}_{1}$ nanocatalysts 


\section{Norilhamiah \& Siti Kartom: PdAu BIMETALLIC CATALYST FOR ELECTROOXIDATION OF GLYCEROL}

USING CYCLIC VOLTAMMETRY ANALYSIS

Table 1. Comparison between measured XRD and EDX results of samples a) $\operatorname{Pd}_{2} \mathrm{Au}_{1}$ and b) $\mathrm{Pd}_{4} \mathrm{Au}_{1}$

\begin{tabular}{llccccc}
\hline Sample & $\begin{array}{l}\text { Catalyst } \\
\text { Types }\end{array}$ & $\mathbf{2 \theta}$ & $\begin{array}{c}\text { Lattice Parameter } \\
(\mathbf{n m})\end{array}$ & $\begin{array}{c}\text { Atomic } \\
\text { Composition } \\
(\mathbf{X R D}) \\
\text { Pd:Au }\end{array}$ & $\begin{array}{c}\text { Atomic } \\
\text { Ratio(EDX) } \\
\text { Pd:Au }\end{array}$ & $\begin{array}{c}\text { Crystallite } \\
\text { Size } \\
(\mathbf{X R D})\end{array}$ \\
\hline $\mathrm{a}$ & $\mathrm{Pd}_{2} \mathrm{Au}_{1}$ & 38.28 & 0.3991 & $65.05: 34.95$ & $71.3: 28.7$ & 6.0 \\
$\mathrm{~b}$ & $\mathrm{Pd}_{4} \mathrm{Au}_{1}$ & 39.15 & 0.3892 & $79.4: 20.6$ & $80.2: 19.8$ & 4.2 \\
\hline
\end{tabular}

The morphology of the synthesised $\mathrm{Pd}_{2} \mathrm{Au}_{1}$ and $\mathrm{Pd}_{4} \mathrm{Au}_{1}$ bimetallic catalysts was evaluated by using FESEM imaging as can be seen in Figure 2. The FESEM images illustrate homogenous nucleation and growth of bimetallic nanoparticles but with little agglomeration successfully generated by trisodium citrate and sodium borohydride reduction method [21]. Figure 3 shows EDX and mapping analysis which confirmed the presence of $\mathrm{Pd}$ and $\mathrm{Au}$ and the distribution of both metal catalysts. XRD results were correlated with EDX measurements to evaluate the bulk composition of both catalysts. Table 1 lists the bulk composition from EDX evaluation for both catalysts which was found to be so close to the nominal value. These results prove that the bulk composition of $\mathrm{Pd}$ and $\mathrm{Au}$ in the synthesis catalysts is in good agreement with the molar ratio of Pd to Au salt in the solution.
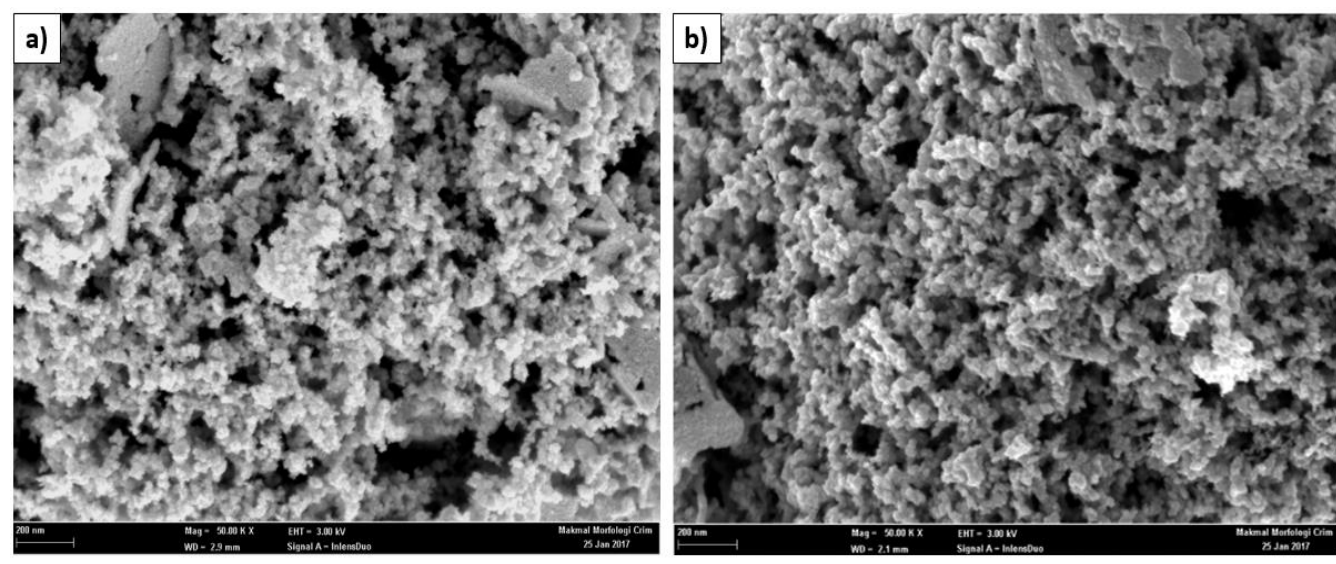

Figure 2. FESEM images of a) $\mathrm{Pd}_{2} \mathrm{Au}_{1}$ and $\left.b\right) \mathrm{Pd}_{4} \mathrm{Au}_{1}$ nanocatalysts

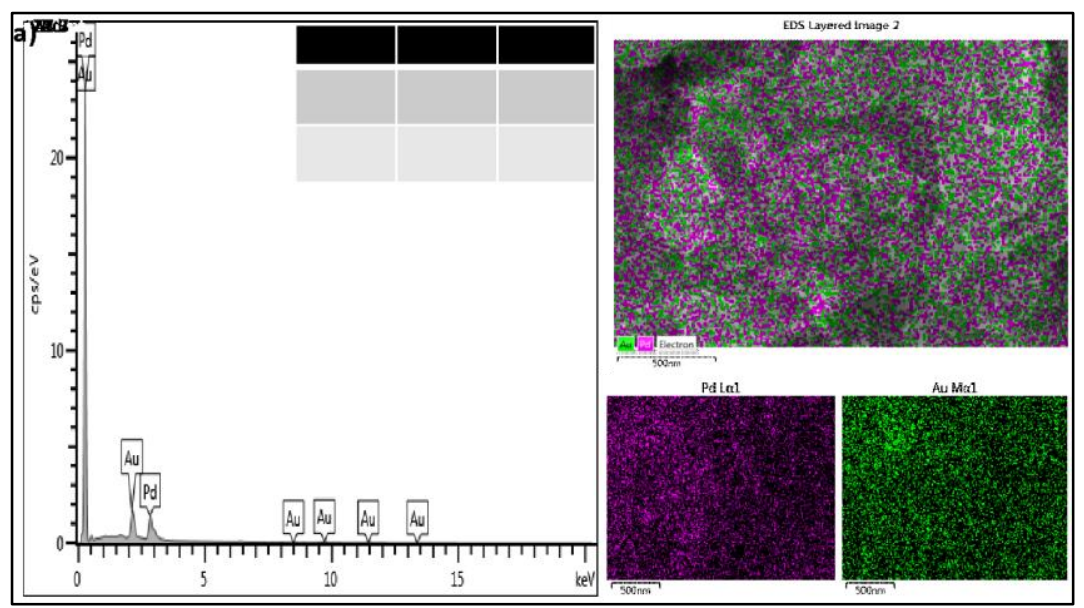




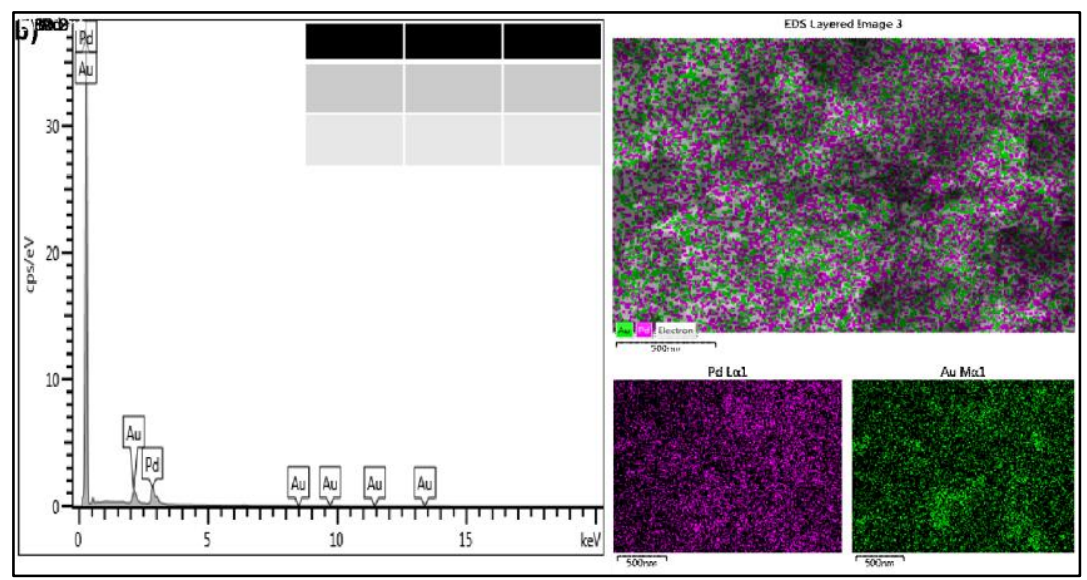

Figure 3. EDX analysis and element mapping on a) $\mathrm{Pd}_{2} \mathrm{Au}_{1}$ and b) $\mathrm{Pd}_{4} \mathrm{Au}_{1}$ nanocatalysts

\section{Cyclic voltammetry study}

The performances of catalysts in glycerol oxidation reaction (GOR) were evaluated in terms of two aspects: (1) onset potential $\left(\mathrm{E}_{\mathrm{on}}\right)$; indicative of the catalytic activity over glycerol oxidation reactions, (2) forward anodic specific peak current density $\left(\mathrm{I}_{\mathrm{f}}\right)$; showing the catalyst maximum performance. In order to acquire the qualitative information for catalysts activity in alkaline media, the typical $\mathrm{CV}$ behaviour of $\mathrm{Pd}_{2} \mathrm{Au}_{1}$ and $\mathrm{Pd}_{4} \mathrm{Au}_{1}$ catalysts were preliminarily investigated in $0.5 \mathrm{M} \mathrm{NaOH}$ without the presence of glycerol as shown in Figure 4. For comparison, the standard $\mathrm{CV}$ for $\mathrm{Pd}_{2} \mathrm{Au}_{1}$ and $\mathrm{Pd}_{4} \mathrm{Au}_{1}$ catalysts is also presented. The strong cathodic peak at $\mathrm{E}=-0.381 \mathrm{~V}$ and $\mathrm{E}=-0.378 \mathrm{~V}$ corresponding to the formation and reduction of palladium oxide in the $\mathrm{CV}$ was obtained from $\mathrm{Pd}_{2} \mathrm{Au}_{1}$ and $\mathrm{Pd}_{4} \mathrm{Au}_{1}$ catalysts, respectively. The electroactive surface area per gram of palladium was achieved by $\mathrm{Pd}_{2} \mathrm{Au}_{1} / \mathrm{VGCNF}$ at $14.12 \mathrm{~m}^{2} / \mathrm{g}_{\mathrm{Pd}}$ and $\mathrm{Pd}_{4} \mathrm{Au}_{1}$ at $12.7 \mathrm{~m}^{2} / \mathrm{g}_{\mathrm{Pd}}$.

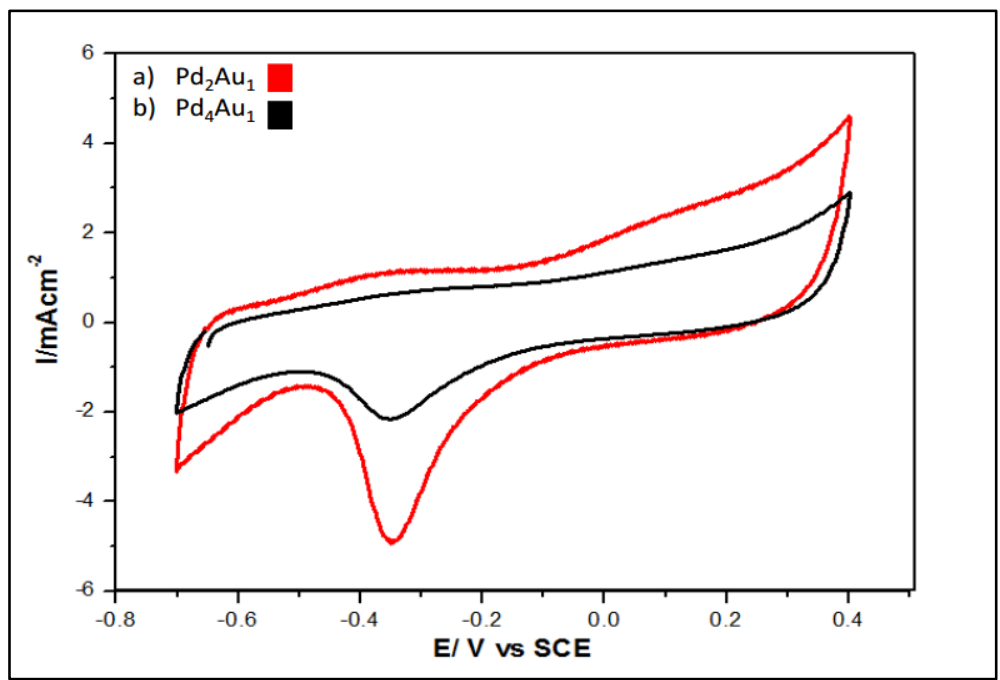

Figure 4. Cyclic voltammograms of a) $\mathrm{Pd}_{2} \mathrm{Au}_{1}$ and b) $\mathrm{Pd}_{4} \mathrm{Au}_{1}$ for the electrooxidation using $0.5 \mathrm{M} \mathrm{NaOH}$ as an electrolyte scan rate of $50 \mathrm{mV} / \mathrm{s}$.

Figure 5 shows the cyclic voltammetry study of glycerol oxidation in the electrolyte solution containing $0.5 \mathrm{M}$ glycerol and $0.5 \mathrm{M} \mathrm{NaOH}$ on different catalysts at a scan rate of $50 \mathrm{mVs}^{-1}$. The electrooxidation of glycerol was characterised by two well-defined current peaks on the forward and reverse scans. In the forward scan, the peak 
corresponded to the oxidation of freshly chemisorbed species coming from the glycerol adsorption and the anodic sweep grew systematically with the increasing values of potential $(\mathrm{V})$. Meanwhile, reverse scan was associated with the removal of carbonaceous species formed during oxidation of glycerol [22]. $\mathrm{The} \mathrm{Pd}_{2} \mathrm{Au}_{1}$ showed more negative onset potential for glycerol oxidation and higher anodic peak for current density $\left(55.28 \mathrm{~mA} \mathrm{~cm}{ }^{-2}\right)$ compared to $\mathrm{Pd}_{4} \mathrm{Au}_{1}\left(41.31 \mathrm{~mA} \mathrm{~cm}{ }^{-2}\right)$. This result shows that the metal compositions of the bimetallic cluster give the greatest effect towards glycerol oxidation. Since the reaction took place in an alkaline medium, the presence of $\mathrm{OH}$ ions will facilitate the active sites on catalyst. As can be seen in Figure 5, the steady-state oxidation forward current $\left(\mathrm{I}_{\mathrm{f}}\right)$ can be detected at the potential above $-0.4 \mathrm{~V}$, which is above the starting potential of the adsorption of the hydroxyl ions (equation 2).

$$
\begin{aligned}
& \mathrm{Pd}+\mathrm{OH}^{-} \leftrightharpoons \mathrm{Pd}_{-} \mathrm{OH}_{\mathrm{ads}}+\mathrm{e}^{-} \\
& \mathrm{C}_{3} \mathrm{H}_{5}(\mathrm{OH})_{3}+12 \mathrm{OH}^{-} \longrightarrow 2 \mathrm{C}_{3} \mathrm{O}_{5}{ }^{2-}+10 \mathrm{H}_{2} \mathrm{O}+10 \mathrm{e}^{-} \\
& \mathrm{C}_{3} \mathrm{H}_{5}(\mathrm{OH})_{3}+20 \mathrm{OH}^{-} \longrightarrow 3 \mathrm{CO}_{3}{ }^{2-}+14 \mathrm{H}_{2} \mathrm{O}+14 \mathrm{e}^{-}
\end{aligned}
$$

The chemisorption of glycerol molecules on oxygen-containing species $\left(\mathrm{Pd}-\mathrm{OH}_{\mathrm{ads}}\right)$ indirectly assisted in getting rid of intermediate species that existed during the dissociative of glycerol molecules [23]. Thus, it allowed further reaction to occur without any difficulty. As a result, GOR will continue the current increase with the increase in potential. Moreover, partial oxidation of glycerol without $\mathrm{C}-\mathrm{C}$ bond breaking and $\mathrm{C}_{3} \mathrm{O}_{5}{ }^{2-}$ production leads to producing $10 \mathrm{e}^{-}$(equation 3). Meanwhile, complete oxidation of glycerol produced $14 \mathrm{e}^{-}$(equation 4) [24]. Furthermore, the addition of a second metal also provided more active sites for the electrooxidation of glycerol, while at the same time controlling the poisoning effect $[25,26]$. The electrochemical active surface area (EASA) value for $\mathrm{Pd}_{2} \mathrm{Au}_{1}$ is higher compared to $\mathrm{Pd}_{4} \mathrm{Au}_{1}$ which is another reason attributed to the better performance of $\mathrm{Pd}_{2} \mathrm{Au}_{1}$ catalyst. The higher EASA refers to more active sites available to adsorb active oxygen atoms which will readily oxidise the intermediate products produced during the oxidation reaction on the catalyst surface. Ratio of current forward to current backward (If:Ib) that reflects the carbon monoxide tolerance shows that $\mathrm{Pd}_{2} \mathrm{Au}_{1}$ is higher compared to $\mathrm{Pd}_{4} \mathrm{Au}_{1}$. Bimetallic effect normally assists the mechanism of $\mathrm{CO}$ tolerance through modification of the electronic structure. Sticking probability of $\mathrm{CO}$ on $\mathrm{Pd}$ surface is reduced by the adjacent $\mathrm{Au}$ which improve the catalytic activity of the catalyst. This inhibits higher ratio of Au which will help to keep more active Pd sites available for glycerol oxidation, and hence provide the high $\mathrm{CO}$ tolerance of the $\mathrm{Pd}_{2} \mathrm{Au}_{1}$ bimetallic catalyst. Table 2 shows performance comparison between $\mathrm{Pd}_{2} \mathrm{Au}_{1}$ and $\mathrm{Pd}_{4} \mathrm{Au}_{1}$ catalysts.

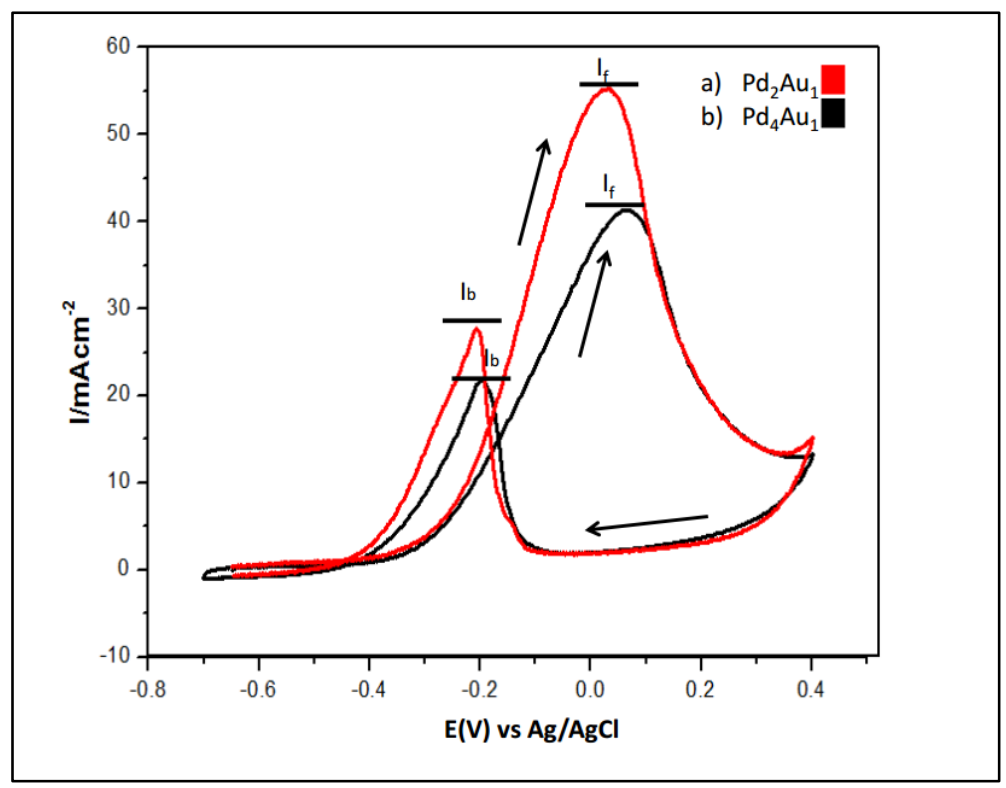

Figure 5. Cyclic voltammograms of a) $\mathrm{Pd}_{2} \mathrm{Au}_{1}$ and b) $\mathrm{Pd}_{4} \mathrm{Au}_{1}$ nanocatalysts for the electrooxidation of $0.5 \mathrm{M}$ glycerol using $0.5 \mathrm{M} \mathrm{NaOH}$ as an electrolyte scan rate of $50 \mathrm{mV} / \mathrm{s}$. 
Table 2. Performance of a) $\mathrm{Pd}_{2} \mathrm{Au}_{1}$ and b) $\mathrm{Pd}_{4} \mathrm{Au}_{1}$ nanoparticles for glycerol electrooxidation in alkaline media

\begin{tabular}{llccccc}
\hline Sample & Catalyst Types & $\begin{array}{c}\text { Eon } \\
(\mathbf{V})\end{array}$ & $\begin{array}{c}\mathbf{I}_{\mathbf{f}} \\
\left(\mathbf{m A c m} \mathbf{c m}^{-2}\right)\end{array}$ & $\begin{array}{c}\mathbf{I}_{\mathbf{B}} \\
\left(\mathbf{m A c m} \mathbf{c m}^{-2}\right)\end{array}$ & $\mathbf{I}_{\mathbf{f}} / \mathbf{I}_{\mathbf{b}}$ & $\begin{array}{c}\text { EASA } \\
\left(\mathbf{m}^{2} \mathbf{g}^{-1}\right)\end{array}$ \\
\hline $\mathrm{a}$ & $\mathrm{Pd}_{2} \mathrm{Au}_{1}$ & -0.4152 & 55.28 & 27.75 & 1.99 & 14.12 \\
$\mathrm{~b}$ & $\mathrm{Pd}_{4} \mathrm{Au}_{1}$ & -0.4295 & 41.31 & 21.84 & 1.89 & 12.7 \\
\hline
\end{tabular}

\section{Chronoamperometry study}

The durability of $\mathrm{Pd}_{2} \mathrm{Au}_{1}$ and $\mathrm{Pd}_{4} \mathrm{Au}_{1}$ bimetallic catalysts during long term operations was evaluated via chronoamperometry curves. Figure 6 illustrates the chronoamperometry measurements for 3600 seconds in electrolyte solution of $0.5 \mathrm{M} \mathrm{NaOH}$ and $0.5 \mathrm{M}$ glycerol. As demonstrated in the chronoamperometry analysis, a decay of current value in the time interval indicates a considerable stability of the catalysts and a tolerance to poisoning by intermediates species. As in the cyclic voltammetry analysis, $\mathrm{Pd}_{2} \mathrm{Au}_{1}$ demonstrated better activity and stability compared to $\mathrm{Pd}_{4} \mathrm{Au}_{1}$. Noticeably, $\mathrm{Pd}_{2} \mathrm{Au}_{1}$ inhibited higher initial current density and limiting current density for a long time. It is shown that the presence of Au could improve the stability of the catalyst by giving a balanced adsorption between $\mathrm{OH}^{-}$species from Au and species from glycerol adsorption on Pd [27]. Nevertheless, the current density reduction occurred too fast for both catalysts. Therefore, it is desirable to introduce a catalyst support to improve the stability of the catalysts.

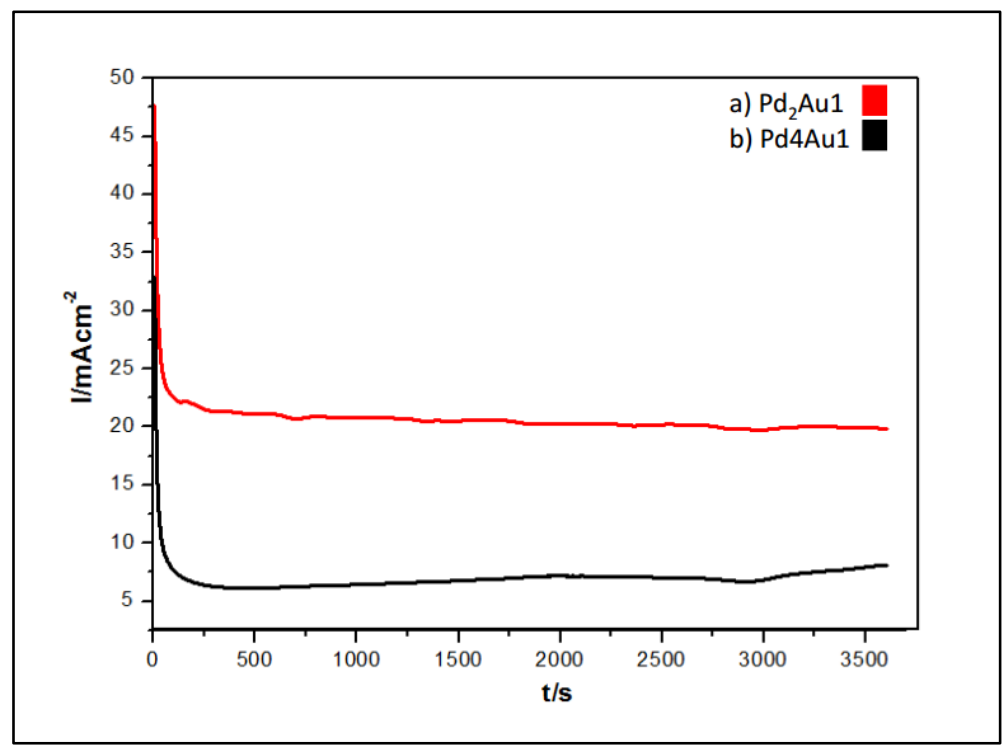

Figure 6. Chronoamperometry analysis of a) $\mathrm{Pd}_{2} \mathrm{Au}_{1}$ and b) $\mathrm{Pd}_{4} \mathrm{Au}_{1}$ for the electrooxidation of $0.5 \mathrm{M}$ glycerol using $0.5 \mathrm{M} \mathrm{NaOH}$ as an electrolyte scan rate of $50 \mathrm{mV} / \mathrm{s}$

\section{Conclusion}

In summary, the two types of catalysts, namely $\mathrm{Pd}_{2} \mathrm{Au}_{1}$ and $\mathrm{Pd}_{4} \mathrm{Au}_{1}$ have been successfully synthesised by the reduction method. XRD data clearly showed the presence of bimetallic $\mathrm{Pd}_{2} \mathrm{Au}_{1}$ and $\mathrm{Pd}_{4} \mathrm{Au}_{1}$ catalysts. These two bimetallic catalysts were compared with each other for the electrooxidation of glycerol in alkaline media. The incorporation of a second metal which is Au modified the electronic configuration of the Pd catalyst which enhanced the activity towards glycerol oxidation. The CV results exhibited that $\mathrm{Pd}_{2} \mathrm{Au}_{1}$ catalyst showed excellent catalytic activity and high stability for glycerol oxidation compared to $\mathrm{Pd}_{4} \mathrm{Au}_{1}$ catalyst. Besides that, it could be observed that the onset potential for glycerol oxidation for $\mathrm{Pd}_{2} \mathrm{Au}_{1}$ was more negative than $\mathrm{Pd}_{4} \mathrm{Au}_{1}$ which was 


\section{Norilhamiah \& Siti Kartom: PdAu BIMETALLIC CATALYST FOR ELECTROOXIDATION OF GLYCEROL USING CYCLIC VOLTAMMETRY ANALYSIS}

attributed to the reaction that occurred faster. This means the improvement was strongly dependent on the composition (atomic $\mathrm{Pd} / \mathrm{Au}$ ratio) of the catalysts. In addition, the $\mathrm{I}_{\mathrm{f}} / \mathrm{I}_{\mathrm{b}}$ ratio which reflected poisoning species for the oxidation of glycerol showed that bimetallic $\mathrm{Pd}_{2} \mathrm{Au}_{1}$ again had higher ratio value which means bimetallic catalyst has a higher tolerance to the poisoning species. The obtained results confirmed the catalytic activity is affected by the presence of bimetallic active phase. The synthesis method for the development of $\mathrm{Pd}$ and $\mathrm{Au}$ bimetallic catalysts could be extended to other compositions in order to improve the catalytic activity of the catalysts and in the meantime minimise the utilisation of the noble metals.

\section{Acknowledgements}

The authors gratefully acknowledge the financial support given for this work by the Universiti Kebangsaan Malaysia (UKM) under DIP-2015-002 and Ministry of Education (MOE) under GSP/1/2015/TK01/UKM/01/1.

\section{References}

1. Kamarudin, M. Z. F., Kamarudin, S. K., Masdar, M. S. and Daud, W. R. W. (2013). Review: Direct ethanol fuel cells. International Journal of Hydrogen Energy, 38(22): 9438-9453.

2. Zainoodin, A. M., Kamarudin, S. K., Masdar, M. S., Daud, W. R. W., Mohamad, A. B. and Sahari, J. (2014). High power direct methanol fuel cell with a porous carbon nanofiber anode layer. Applied Energy, 113: 946954.

3. Bambagioni, V., Bianchini, C., Marchionni, A., Filippi, J., Vizza, F., Teddy, J., Serp, P. and Zhiani, M. (2009). $\mathrm{Pd}$ and Pt-Ru anode electrocatalysts supported on multi-walled carbon nanotubes and their use in passive and active direct alcohol fuel cells with an anion-exchange membrane (alcohol = methanol, ethanol, glycerol). Journal of Power Sources, 190(2):241-251.

4. Thiam, H. S., Daud, W. R. W., Kamarudin, S. K., Mohammad, A. B., Kadhum, A. A. H., Loh, K. S., and Majlan, E. H. (2011). Overview on nanostructured membrane in fuel cell applications. International Journal of Hydrogen Energy, 36(4):3187-3205.

5. Basri, S., Kamarudin, S. K., Daud, W. R. W. and Yaakub, Z. (2010). Nanocatalyst for direct methanol fuel cell (DMFC). International Journal of Hydrogen Energy, 35(15): 7957-7970.

6. Zhiani, M., Rostami, H., Majidi, S., and Karami, K. (2013). Bis (dibenzylidene acetone) palladium (0) catalyst for glycerol oxidation in half cell and in alkaline direct glycerol fuel cell. International Journal of Hydrogen Energy, 38(13):5435-5441.

7. Habibi, E. and Razmi, H. (2012). Glycerol electrooxidation on Pd, Pt and Au nanoparticles supported on carbon ceramic electrode in alkaline media. International Journal of Hydrogen Energy, 37(22): 16800-16809.

8. Yang, F., Hanna, M. A. and Sun, R. (2014). Value-added uses for crude glycerol-a byproduct of biodiesel production. Biotechnology for Biofuels, 5: 13.

9. Li, S. S., Hu, Y. Y., Feng, J. J., Lv, Z. Y., Chen, J. R., and Wang, A. J. (2014). Rapid room-temperature synthesis of Pd nanodendrites on reduced graphene oxide for catalytic oxidation of ethylene glycol and glycerol. International Journal of Hydrogen Energy, 39(8): 3730-3738.

10. Bagheri, S., Julkapli, N. M. and Yehye, W. A. (2014). Catalytic conversion of biodiesel derived raw glycerol to value added products. Renewable and Sustainable Energy Reviews, 41: 113-127.

11. Pagliaro, M., Ciriminna, R., Kimura, H., Rossi, M. and Della, Pina C. (2007). From glycerol to value-added products. Angewandte Chemie - International Edition, 46(24): 4434-4440.

12. Liu, J. (2017). High performance platinum single atom electrocatalyst for oxygen reduction reaction. Nature Communications, 8: 15938.

13. Newton, M. A., Ferri, D., Smolentsev, G., Marchionni, V. and Nachtegaal, M. (2015). Room-temperature carbon monoxide oxidation by oxygen over $\mathrm{Pt} / \mathrm{Al}_{2} \mathrm{O}_{3}$ mediated by reactive platinum carbonates. Nature Communications, 6: 1-7.

14. Ruvinsky, P. S., Pronkin, S. N., Zaikovskii, V. I., Bernhardt, P. and Savinova, E. R. (2008). On the enhanced electrocatalytic activity of $\mathrm{Pd}$ overlayers on carbon-supported gold particles in hydrogen electrooxidation. Physical Chemistry Chemical Physics, 10(44): 6665-6676.

15. Meng, H., Zeng, D. and Xie, F. (2015). Recent development of Pd-based electrocatalysts for proton exchange membrane fuel cells. Catalysts, 5(3): 1221-1274.

16. Niu, Z. and Li, Y. (2014). Removal and utilization of capping agents in nanocatalysis. Chemistry of Materials, 26(1): 72-83. 
17. Qin, Y. H., Jia, Y. B., Jiang, Y., Niu, D. F., Zhang, X. S., Zhou, X. G., Niu, Li. and Yuan, W. K. (2012). Controllable synthesis of carbon nanofiber supported Pd catalyst for formic acid electrooxidation. International Journal of Hydrogen Energy, 37(9): 7373-7377.

18. Marshall, A. T., Golovko, V. and Padayachee, D. (2015). Influence of gold nanoparticle loading in Au/C on the activity towards electrocatalytic glycerol oxidation. Electrochimica Acta, 153: 370-378.

19. Yan, W., Tang, Z., Wang, L., Wang, Q., Yang, H. and Chen S. (2016). PdAu alloyed clusters supported by carbon nanosheets as efficient electrocatalysts for oxygen reduction. International Journal of Hydrogen Energy, 42(1): 218-227.

20. Wang, W., Kang, Y., Yang, Y., Liu, Y., Chai, D. and Lei Z. (2015). PdSn alloy supported on phenanthrolinefunctionalized carbon as highly active electrocatalysts for glycerol oxidation. International Journal of Hydrogen Energy, 41(2): 1272-1280.

21. Thottoli, A. K., Kaliani A. and Unni A. (2013). Effect of trisodium citrate concentration on the particle growth of $\mathrm{ZnS}$ nanoparticles. Journal of Nanostructure Chemistry, 3(1): 56.

22. Chen Z., Wang, S., Lian, C., Liu, Y., Wang, D., and Chen, C. (2016). Nano PdAu bimetallic alloy as an effective catalyst for the Buchwald - Hartwig reaction. Asian Journal Communication, 351-355.

23. Liang, Z. X., Zhao, T. S., Xu, J. B. and Zhu, L. D. (2009). Mechanism study of the ethanol oxidation reaction on palladium in alkaline media. Electrochimica Acta, 54(8): 2203-2208.

24. Simões, M., Baranton, S. and Coutanceau, C. (2010). Electro-oxidation of glycerol at Pd based nano-catalysts for an application in alkaline fuel cells for chemicals and energy cogeneration. Applied Catalysis B: Environmental, 93: 354-362.

25. Mahapatra, S. S. and Datta, J. (2011). Characterization of Pt-Pd/C electrocatalyst for methanol oxidation in alkaline medium. International Journal of Electrochemistry, 2011: 1-16.

26. Mao, H., Huang, T. and Yu A. (2016). Surface noble metal modified PdM/C (M 1/4 Ru, Pt, Au) as anode catalysts for direct ethanol fuel cells. Journal of Alloy and Compound, 676: 390-396.

27. Thi, B., Lam, X., Chiku, M., Higuchi, E. and Inoue H. (2015). Preparation of PdAg and PdAu nanoparticleloaded carbon black catalysts and their electrocatalytic activity for the glycerol oxidation reaction in alkaline medium. Journal of Power Sources, 297: 149-157. 